DOI 10.31558/2075-2970.2019.37.2

УДК 821.111 .09

ORCID ID: 0000-0002-3512-0315

ORCID ID: 0000-0003-4435-9149

(C) О. С. Бойван, М. Д. Дзюбан

(м. Вінниця)

\title{
ГУМАННИЙ АСПЕКТ \\ ЯК СКЛАДОВА КОНЦЕПТУ «ЖЕРТОВНІСТЬ» У ТВОРАХ ОСКАРА ВАЙЛЬДА
}

Анотація. У статті акцентується увага на важливості розуміння та сприйняття концепту «жертовність» і його гуманної складової на прикладах творів Оскара Вайльда. За матеріал дослідження було обрано казки О. Вайльда, оскільки у них втілено основний життєвий принцип автора, відповідно до якого творчість не є «імітацією життя», так як «описує те, чого ніколи не було», а глибинним баченням реальності у всіх іï фантасмагоричних проявах. Було виконано детальний опис казок "The Nightingale and the Rose", “The Hарру Prince”, “The Devoted Friend”, оскільки вважаємо, що на прикладі цих творів можна вдало відтворити й охарактеризувати зазначену проблематику дослідження. Визначено поняття «жертовність» як потенційну складову системи особистісних вартостей, що сприяє становленню й розвитку вольового зусилля через призму внутрішніх переживань та почуттів. Тут втілюється єдність свідомості, почуття і поведінки, тобто «слово не розходиться 3 ділом». Разом 3 тим, відмічено, що сьогодні посилюється інтерес до проблем таких мовно-філософських концептів як: «любов», «великодушність», «жертовність», «естетизм», «свобода» у творчості О. Вайльда.

Ключові слова: гуманізм, жертовність, особистісні цінності, моральні цінності, свідомий вибір.

Olesia Boivan, Mariia Dziuban HUMANE ASPECT AS THE COMPONENT OF THE CONCEPT SACRIFICING IN THE LITERARY WORKS OF OSCAR WILDE

Abstract. In the article, special attention is paid to the importance of understanding and perception of the concept SACRIFICING and its humane component basing on the examples of famous literary works by Oscar Wilde. We chose Wald's fairy tales as the material of the study, because they embodied the author's basic life principle, according to which creativity is not an 'imitation of life' since it 'describes what never happened', but a deep vision of reality in all its phantasmagoric manifestations. Moreover, it is in his tales that Oscar Wilde is more drawn to eternal values: love, compassion, sacrifice for the sake of the pleasure of others. The artist's storytelling style is full of morality, where the main issues are human feelings and relationships. We consider that the fairy-tales "The Nightingale and the Rose", "The Happy Prince", "The Devoted Friend" are the best examples of reproducing and describing the key points of our research. The concept of SACRIFICING was defined as a potential component of the personal values system, which facilitates the establishment and development of will efforts through the prism of the inner experiences and senses. Unity of consciousness, sense, and behavior is concentrated here with the meaning 'actions speak louder than a thousand words'. At the same time, it is noted by us, that today's interest to the Wilde's problems of certain philosophical concepts as 'love', 'generosity', 'sacrificing', 'aestheticism', 'freedom' is constantly increasing.

Key words: humanism, sacrificing, personal values, moral values, conscious choice. 


\section{1. Вступ}

Сьогодні, у час прискореного розвитку прогресивних технологій, коли тепм життя стає 3 кожним прийдешнім днем швидшим і мобільнішим, особливо гостро відчувається проблема нестачі високоморальних принципів людини, iї гуманних настанов, оскільки це легко втратити або загубити у вирі повсякдення. Часто звертаємось до класичної літератури як джерела натхнення й окриленості для доброчинних діянь та позитивного сприйняття реальності. У нашому дослідженні за таку основу відібрані три відомих твори Оскара Вайльда “The Nightingale and the Rose”, “The Happy Prince”, “The Devoted Friend”, що стали ключовими для характеристики гуманного аспекту як невід’ємної складової концепту «жертовність».

Постановка проблеми. Незаперечним є той факт, що гуманізм та його аналогічні прояви належать до визначальних, основоположних і наскрізних принципів для усієї європейської літературно-мовної традиції, іiі історичної долі. Це система філософських поглядів та соціальних понять, що історично змінювались, але основою завжди, у всі часи залишалася беззаперечна цінність особистості, іiї право на свободу, щастя, розкриття й розвиток власних талантів. Із розвитком гуманістичних тенденцій особлива роль відводиться позитивним емоційним переживанням, що сприяють розвитку експресивних здібностей та умінь. Це, в свою чергу, забезпечує активізацію оптимістично-альтруїстичних настроїв, внутрішню мотивацію, підсилює і покращує ефект будь-якої діяльності й може стати результатом вияву концепту жертовності, підкреслюючи iї праведну ідейність та сподівання.

Золоте правило гуманізму було виведене більше двох з половиною тисячоліть назад трьома давньогрецькими мудрецями. Клеобул стверджував: «Того, що викликає в тебе почуття ненависті, не бажай іншим»; Піттак наголошував: «Що обурює тебе в ближньому, не роби сам»; Фалес на запитання: «Як прожити найкраще і праведне життя?»- відповів: «Не роби того, що засуджуєш в інших». Думки давньогрецьких вчених поділяли давньоіндійський учитель Хилел, який радив: «Не роби нікому того, чого не хочеш, щоб було зроблено і тобі» та Конфуцій (Spyrkyn, 1999, p. 24-26).

Відомий філософ і богослов П. Абеляр був переконаний у тому, що узгодженість із власною совістю виступає критерієм моральності особистості. Коли людина йде на порушення моралі, всупереч совісті, вона глушить ії голос у собі і виникає зло (Abelyar, 2007). Не менш важливу роль у формуванні внутрішнього світу особистості та іï жертовно-гуманного ставлення до оточуючих відіграють духовні цінності (наука, культура, мистецтво, релігія, література тощо), які забезпечують інтелектуальний, моральний, естетичний розвиток особистості.

Зазначені теоретичні аспекти стали окремими основоположними ідеями деяких творів відомого літературного діяча Оскара Вайльда. Сьогодні досліджуються різні проблеми та джерела його творчості: моральні (у нашому випадку - це прояви жертовності), філософські, стилістичні. Варто зазначити, що характер публікацій про талановитого й ексцентричного письменника істотно змінився, з'явилося багато досліджень, що свідчать про відродження серйозного інтересу до його суперечливої й діалектичної творчості. Разом 3 тим посилюється увага до проблем певних мовно-філософських концептів: «любов», «великодушність», «жертовність», «естетизм», «свобода» у творчості О. Вайльда.

Аналіз останніх досліджень і публікацій. У науковій літературі наводяться різні підходи до розуміння і сприйняття гуманності як програми духовного оновлення. Розгляд таких програм в історичному контексті і їх пропаганда мислителями, що мають свої чіткі межі, 
окреслені й відомі як періоди розвитку людських цивілізацій - античний, середньовічний, ренесансний, християнський, просвітницький і новітньо-гуманістичний. Усі ці історично-обумовлені програми гуманного становлення людської особистості спроектовані на нематеріальних засадах про ідеальну, бажану сутність людини, як правило, обмежені реаліями повсякдення. Але потреба в гуманістичних прагненнях і настановах ніколи не зменшується, бо саме навколо них концентрується культура людинолюбства та жертовності.

Найбільш відомими представниками гуманістичної психології є Дж. Готтер, А. Маслоу, К. Роджерс, Е. Фром та ін. Вони стверджували, що людина за своєю природою добра, що їі прагнення конструктивні та позитивні. Якщо людина діє деструктивно, якщо вона агресивна й зухвала, то не тому, що має таку внутрішню натуру, а тому, що діє проти своєї природи, бо дійсність, в якій вона живе, блокує розвиток ії реальних, позитивних дій (Fromm, 1999, p. 9).

Природу літературних феноменів в контексті творчості О. Вайльда аналізують О. К. Денисова, Ю. Я. Кіссел, Н. Ю. Шпекторова, Н. Т. Федоренко. Вони доводять, що особливості Вайльдівського стилю являють собою структурно-семантичну єдність, в якій стилістичні ефекти породжуються різними порушеннями семантичного та семантико-синтаксичного поєднання їх компонентів.

Коментарі та передмови до різних видань митця створюються зусиллями С. Белзи, К. Чуковського, Б. І. Колесникова і О. К. Піддубного, В. Чухно, А. В. Слобожан. Казки О. Вайльда згадуються в книгах Є. П. Брандіс, Е. В. Померанцева і С. Бойко, присвячених вивченню світового казкового фонду.

Отже, метою статті є характеристика гуманного аспекту як незамінної складової ключового концепту «жертовність» на прикладах відомих творів Оскара Вайльда. Особлива увага приділяється казкам “The Nightingale and the Rose”, “The Happy Prince”, "The Devoted Friend”, оскільки вважаємо, що на прикладі цих творів можна вдало відтворити й охарактеризувати зазначену проблематику дослідження. Жертовність - моральна установка, що припускає граничну безкорисливість по відношенню до іншого, включаючи готовність до реального відступу від власних інтересів на користь людей (Khrystofora, 2019).

На основі аналізу філософської, історичної, психологічної, педагогічної літератури у нашому дослідженні було визначено поняття жертовність як потенційну складову системи особистісних вартостей, щзо сприяє становленню й розвитку вольового зусилля через призму внутрішніх переживань та почуттів. Тут втілюється єдність свідомості, почуття $і$ поведінки, тобто «слово не розходиться з ділом».

\section{2. Виклад матеріалу}

Із поняттям жертовність ми звикли асоціювати виняткові подвиги, страждання, муки, коли хтось у буквальному розумінні віддає власне життя задля блага інших. Однак жертовність не вичерпує себе героїчною поведінкою в екстремальних обставинах. Вона потрібна у щоденному житті, у простих, маленьких діях. Жертовність - це добровільне віддавання себе, власного «я» іншій особистості, це вихід назустріч іншому для служіння йому. Вона не має нічого спільного з самоприниженням чи самозапереченням; це свідомий і добровільний вибір особистості, продиктований іï моральними цінностями. Жертовність $є$ однією з найвищих форм любові, вона може виявляти себе в подружніх і родинних стосунках, у дружбі, на місці праці - скрізь, де своїй поведінці, своїй діяльності людина свідомо надає форми щирого і само- 
відданого служіння, тобто це почуття здатне лише збагачувати, надихати і животворити (Khrystofora, 2019).

Коли говоримо про поняття «жертовність», зразу ж виринають у пам’яті різні варіації цього світовідчуття у щоденних реаліях, а саме: материнська або батьківська жертовність, відданість патріотичним ідеям і любові до Батьківщини, жертовність заради друга, брата тощо. Візьмемо для прикладу історію священника Максиміліана Кольбе. 17 лютого 1941 р. Максиміліан Кольбе був заарештований гестапо і поміщений у в'язницю Павяк. 25 травня того ж року його перевели в Аушвіц. Він отримав номер 16670. Есесівці постійно били його кованими чобітьми, примушували носити непідйомні вантажі (це при тому, що він був калікою, хворим на туберкульоз, у нього була тільки одна легеня), але він не тільки зберігав силу духу, але й іншим допомагав. Навіть у таких нелюдських умовах Максиміліан продовжував свою пастирську діяльність - втішав, хрестив, сповідав, пошепки здійснював богослужіння. У липні 1941 року з блоку № 14, в якому жив отець Максиміліан, зник ув’язнений. Утікача знайти не вдалося (пізніше з'ясувалося, що він потонув у вигрібній ямі). Тоді заступник коменданта табору відібрав 10 осіб, яким було призначено померти голодною смертю у блоці № 13, наводячи жах на весь табір. Це покарання було призначене як «виховання» та залякування ув'язнених, щоб більше ніхто не намагався тікати. Один з відібраних ними людей, польський сержант Франтішек Гаєвнічек заплакав і сказав: «Невже я більше не побачу дружину і дітей? Що ж тепер з ними буде?» I тоді Кольбе вийшов зі строю і запропонував своє життя в обмін на життя Гаєвнічека. Жертва була прийнята (Кольбе).

Як бачимо, це яскравий приклад чіткої спроможності діяти проти задоволення власних потреб з прагматичними тенденціями, це саме та ціннісно-особистісна орієнтація, яка спонукає нас відходити від егоцентричних прагнень, поставивши інтереси свого ближнього вище за свої, оскільки саме такі особистості є цілісними натурами (духовно і фізично) і мають глибоку гармонію у розумінні вищих нематеріальних чинників.

Такі жертовно-гуманні характеристики є основоположними у казках Оскара Вайльда, який вважається одним з найяскравіших та найталановитіших англійських письменників другої половини XIX сторіччя. Він акцентував увагу на естетиці почуттів основою яких є протилежності та контроверсійні принципи. Внесок цього співця краси до скарбниці світової літератури неможливо оцінити - кожен з його творів, від ранніх віршів до філософських казок має повне право називатися літературним безцінним надбанням. Оскар Вайльд випустив два збірники казок: «Щасливий принц» в 1888 році й три роки через - «Гранатовий будиночок», у яких своєрідно, можна сказати стильно, висвітлив складні й суперечливі філософські думки. Письменник називав свої казки етюдами в прозі й адресував їх читачам усіх вікових категорій.

Саме у казках письменник яскраво проявив багатство своєї уяви та неперевершену майстерність володіння словом. Жанр казкової оповіді розкриває для митця широкі можливості використання різноманітних художніх засобів та дозволяє виражати свої ідеї в незвичайній, фантастичній формі. У казках автор висловлює свої погляди на світ, мистецтво, суспільні відносини; саме в казках можливо помітити повною мірою особливості художнього почерку О. Вайльда, властиві йому парадоксальність та суперечливість мислення та любов до барвистих описів. Особливо цікавим є вивчення емоційно-вольового аспекту головних героїв у його казках.

Казки написані не тільки для дітей, а й для дорослих, які «не втратили здатності радіти i дивуватися». У них багато моральних моментів і пошук правильності у ціннісному аспекті 
суджень головних героїв. Свої казки автор назвав «чарівними оповіданнями». Цим він підкреслив, що його твори не позбавлені новелістичної традиції і піднімають головну тему - любов агапе (Божа, безумовна, жертовна, дієва, вольова, турботлива любов). Грецькі філософи за часів Платона вживали цей термін для визначення любові до істини чи людей і в основному 3 трагічним фіналом. Так само й твори митця наповнені певними екзотичними описами природи й самоцінності людини, що допомагають читачеві зрозуміти співвідношення категорії краси любові та жертовності, але за високу ціну.

Казка Оскара Вайльда «Щасливий принц» сприймається читачем чи шанувальником його творчості як одна з найгарніших і найцікавіших. Ї̈̈ зміст дуже простий. Здіймаючись до висот справжньої моральності і правдивого розуміння краси душі, вона навчає, що доброта завжди вимагає любові й жертви. У казці «Щасливий принц» головний герой не знав горя, страждань i сліз. Його палац Безтурботності був розташований за високим муром, який відмежовував прекрасний сад від міста та його повсякденних реалій: "High above the city, on a tall column, stood the statue of the Happy Prince. He was gilded all over with thin leaves of fine gold, for eyes he had two bright sapphires, and a large red ruby glowed on his sword-hilt” 'Над містом на високій колоні стояла статуя Щасливого Принца. Він увесь сяяв, покритий тонкими листами справжнього золота; замість очей у нього були два блискучі сапфіри, а на руків”ї шпаги сяяв великий червоний рубін'.

Всі захоплюються красою золотого Принца. Дівчата кажуть, що він схожий на янгола зі сну, мами ставлять дітям «слухняну» статую за приклад, поціновувачі мистецтва хвалять витонченість коштовних оздоблень: "He was very тисh admired indeed. "He is as beautiful as a weathercock, - remarked one of the Town Councillors who wished to gain a reputation for having artistic tastes; only not quite so useful, - he added, fearing lest people should think him unpractical, which he really was not. "Why can't you be like the Happy Prince?" - asked a sensible mother of her little boy who was crying for the moon. "The Happy Prince never dreams of crying for anything" (Wilde) 'Вона прекрасна, як флюгер-півень, - сказав міський радник, котрий прославився своїм художнім смаком. Хоча, звичайно, користі з неї менше, - додав він, побоюючись, щоб його не запідозрили в непрактичності.

- Чому ти не такий, як Щасливий Принц? - скрушно зітхнула розсудлива мати над своїм маленьким синком, який плакав, просячи, щоб йому зняли місяць із неба. - Щасливий Принц ніколи не вередує'.

Як бачимо, лише після смерті герой зміг пізнати жаль та смуток людей, навчився співчувати їм, сльози котилися із сапфірових очей його позолоченої статуї, що стояла на високій колоні над містом. Але знаходячись у нерухомому стані, Принц уже нічим не міг зарадити. Щире співчуття народжувалося в глибинах його штучного, закам'янілого єства, яке готове було жертвувати усіма коштовностями, які він так обожнював за життя. Пізно ввечері статуя заговорила з Ластівкою, яка залишилася у великому місті на нічліг, але на наступний день птах мав рішучий намір полетіти у теплі краї: “...I did not know what tears were, for I lived in the Palace of Sans-Souci, where sorrow is not allowed to enter. In the daytime I played with my companions in the garden, and in the evening I led the dance in the Great Hall. Round the garden ran a very lofty wall, but I never cared to ask what lay beyond it, everything about me was so beautiful. My courtiers called me the Happy Prince, and happy indeed I was, if pleasure be happiness. So I lived, and so I died. And now that I am dead they have set me up here so high that I can see all the 
ugliness and all the misery of my city, and though my heart is made of lead yet I cannot chose but weep”. ‘... я не знав, що таке сльози, бо жив у палаці Сан-Сусі, куди заборонено заходити журбі. Удень я розважався з своїми друзями в саду, а ввечері танцював на балу у великій залі. Сад був обгороджений височезною стіною, але я ніколи не питав, що там за нею, адже навколо мене була така краса. Мої придворні називали мене Щасливим Прийдем, і я справді був щасливим, бо вважав, що щастя в насолоді. Так я жив, так і помер. І от тепер, коли я неживий, мене поставили на цій колоні так високо, що мені стало видно лихо і злидні, які панують у моєму місті, і хоч моє серце із свинцю, проте я не можу стримати сліз'.

Виявилося, що душа Принца переселилася в цю прекрасну статую, і з висоти своєї мертвої розкоші він бачить всі біди і нещастя бідних людей, про які й гадки не мав за життя в палаці. Він дуже хотів допомогти біднякам, от і попросив Ластівку віднести хворому хлопчику рубін зі свого меча: "In a bed in the corner of the room her little boy is lying ill. He has a fever, and is asking for oranges. His mother has nothing to give him but river water, so he is crying. Swallow, Swallow, little Swallow, will you not bring her the ruby out of my sword-hilt? My feet are fastened to this pedestal and I cannot move” (Wilde). 'В кутку на ліжку лежить ¥ї хворий синок. У нього гарячка, і він просить апельсинів. А у матері нема чого йому дати, окрім річкової води, і хлопчик плаче. Ластівко, Ластівко, маленька Ластівко! Прошу тебе, віднеси їй рубін із руків’я моєї шпаги! Мої ноги прикуті до п’єдесталу, і я не можу зрушити з місця'.

Як бачимо, лише будучи в нерухомому стані, навіки прикутим до свого п’єдесталу, Принц зумів осягнути таємницю любові агапе й зрозуміти, що високе почуття жертовності осягається лише в сприйнятті власної самоцінності та шануванні інтересів інших людей. Але недостатньо просто стояти і співчувати, потрібно робити вчинки, які свідчитимуть найкраще про його високі прагнення. Маленька пташина змогла відчути істинність його переживань i стала його помічником у реалізації гуманних задумів, оскільки мала міцні крила і відкрите, співчутливе серце. День за днем Ластівка знімала з Принца шматочки позолоти, дорогоцінне каміння і відносила їх бідним та стражденним. Звичайно, для цих людей то було справжнім чудом, дароване небом. Зароджувались паростки надії на краще життя, коли не відчуваєш голоду, холоду, біди та болю: "Leaf after leaf of the fine gold the Swallow picked off, till the Happy Prince looked quite dull and grey. Leaf after leaf of the fine gold he brought to the poor, and the children's faces grew rosier, and they laughed and played games in the street” (Wilde). 'Листок за листком справжнього золота знімала Ластівка, аж доки Щасливий Принц став зовсім сірий і негарний. Листок за листком справжнього золота відносила вона біднякам, і личка їхніх дітей рожевіли, вони сміялися й гралися на вулицях'.

Рятуючи інших, допомагаючи Принцу полегшити муки його совісті, Ластівка загинула за безцінну жертовно-гуманну ідею. Таким способом письменник прагнув показати утилітарний, занадто практичний підхід до розуміння краси душі, внутрішніх благородних прагнень. Птах просто не мав фізичних можливостей вижити в суворих умовах зими, коли важко знайти теплий куточок і щось попоїсти. Але його велика й благородна місія незамінного помічника Принца і рятівника людських доль була повністю виконана: "It is not to Egypt that I am going," said the Swallow. "I am going to the House of Death. Death is the brother of Sleep, is he not?" And he kissed the Happy Prince on the lips, and fell down dead at his feet. At that moment a curious crack sounded inside the statue, as if something had broken. The fact is that the leaden heart had snapped right in two. It certainly was a dreadfully hard frost”' (Wilde). 'Нi, я лечу не в Сгипет, - 
відповіла Ластівка, - я лечу в дім Смерті. I вона поцілувала Щасливого Принца в уста і впала мертва до його ніг. Цієї ж миті всередині статуї пролунав дивний звук, - наче щось луснуло. А сталося ось що: його свинцеве серце тріснуло і розкололося надвоє. Адже мороз був страх який лютий'.

Найбільш емоційно-вражаючим епізодом казки є фінальна сцена розмови Бога й Ангелів. Стає зрозумілим, що найбільш ціннісними речами з усього міста виявилися мертва Ластівка та свинцеве серце Принца, яке не розплавилось у вогняній печі. Яскраві, виразні приклади жертовності заради когось або ж заради чогось, не чекаючи подяки й поклоніння, возвишення й похвали. Такий сумний, песимістичний, але водночас натхненний фінал може створити хибне враження, ніби добрі вчинки героїв не схвалюються, оскільки вони не отримують за них жодної винагороди, як того вимагають традиції казкового жанру. Але їх нагорода не $\epsilon$ зрозумілою для людських матеріальних потреб, вони отримали безцінну винагороду святості через власну жертовність. Вони зуміли усвідомити й прийняти найвищі людські цінності - любов, доброту, милосердя тощо, які часто просто тонуть у вирі наших турбот і постійної метушні.

"Bring me the two most precious things in the city, - said God to one of His Angels; and the Angel brought Him the leaden heart and the dead bird. "You have rightly chosen, - said God..." (Wilde). 'I звелів Бог ангелові своєму: «Принеси мені дві найцінніші речі, які є в цьому місті». I приніс йому ангел свинцеве серце та мертву пташку. «Ти правильно вибрав», - сказав Бог’.

Як бачимо, визначальними рисами образів головних героїв казки були: жертовність, альтруїзм, здатність безкорисливо дбати не про себе, а передусім про інших, хто мав менше можливостей або опинився у несподіваній життєвій халепі, крім того, Ластівка та Принц відзначалися незламністю, витримкою, готовністю мужньо терпіти будь-які, навіть найстрашніші, муки заради ідеї, в правильності якої вони переконані.

У казці «Соловей і троянда» автор розповів про Солов'я, який, співчуваючи сльозам закоханого, щиро вірячи у силу й щирість кохання, примусив розцвісти трояндовий кущ: притиснувшись грудьми до трояндової колючки, стікаючи кров'ю, він усю ніч співав пісні. Своїм чарівним співом і життям заплатив Соловей за здійснення дива. Співчуття Солов'я було таким безмежним, що він був готовий віддати все, аби допомогти йому завоювати любов дівчини. Це могла зробити тільки червона троянда, проте ціна за неї була занадто висока - життя Солов'я: "If you want a red rose, - said the Tree, you must build it out of music by moonlight, and stain it with your own heart's-blood". "You must sing to me with your breast against a thorn. All night long you must sing to me, and the thorn must pierce your heart, and your life-blood must flow into my veins, and become mine” (Wilde). 'Якщо тобі потрібна червона троянда, - почало Деревце, - ти маєш створити іiі з музики при місячному сяйві та напоїти кров’ю власного серця. Ти маєш співати для мене, проштрикнувши серце одним із моїх шипів. Цілу ніч ти маєш співати для мене, а шип увіп'ється тобі просто в серце, і твоя кров, твоє життя переллються у мої вени і стануть моїми'.

Більше за усі скарби, понад усе любив Соловей життя. Доречі, маленький соловейко - це втілення образу людини, якій властиві щирі переживання та почуття до інших, коли є розуміння чужої біди та горя, а також щире співчуття стражданням інших. Він цінував кожен момент свого існування: "Death is a great price to pay for a red rose, - cried the Nightingale, and Life is very dear to all. It is pleasant to sit in the green wood, and to watch the Sun in his chariot of gold, and the Moon in her chariot of pearl”' (Wilde). 'Смерть - величезна ціна за одну червону 
троянду, - простогнав Соловей, - а життя дуже дороге для всіх. Як приємно мешкати у зеленому гаї, милуватися Сонцем у золотій колісниці та Місяцем у колісниці з перлів'.

Проте для нього воно не виявилось дорожчим, ніж щастя та кохання Студента. Йому не знадобилося багато часу, щоб прийняти це болюче, проте єдине вірне рішення, здійснити найвеличнішу самопожертву, на яку тільки здатна маленька пташка. Своїми словами він дав зрозуміти, наскільки незначущим є його життя порівняно з великою любов'ю, на яку спроможне тільки людське серце: “...Sweet is the scent of the hawthorn, and sweet are the bluebells that hide in the valley, and the heather that blows on the hill. Yet Love is better than Life, and what is the heart of a bird compared to the heart of a man?...” (Wilde). 'Як солодко пахне глід, які ніжні дзвоники, що ховаються у долині, як буяє верес на пагорбах! Але Кохання важливіше за Життя, і що таке серце однієї пташки порівняно з серцем людини?'

Помираючи заради щастя іншої людини, Соловей своїми останніми нотами оспівав красу своїх моральних цінностей, що спонукали його до цього вчинку - красу, мудрість, відданість та самопожертву. Саме приносячи в жертву своє серце він хотів відчути силу справжньої любові: "Be happy, - cried the Nightingale, be happy; you shall have your red rose. I will build it out of music by moonlight, and stain it with my own heart's-blood. All that I ask of you in return is that you will be a true lover, for Love is wiser than Philosophy, though she is wise, and mightier than Power, though he is mighty” (Wilde). 'Ти будеш щасливим, - вигукнув Соловей, Ти будеш щасливим! Ти отримаєш свою червону троянду. Я створю їі з музики при місячному сяйві та напою іiі кров'ю власного серця. Все, що я попрошу в тебе за це,- щоб ти був справжнім закоханим, бо Кохання мудріше за Філософію, хоч та й мудра, і дужче за Владу, хоч та й дужа'.

Але його безкорисливість, його жертву ціною життя не прийняли й не оцінили, не принесла вона щастя і закоханому. Через примху красуні троянду, здобуту ціною життя Солов'я, викинули на шлях і колесо воза знищило їі. Спаплюжена троянда є символом оманливих, нещирих почуттів, якими ми нищимо благі наміри інших “...What a silly thing Love is, - said the Student as he walked away. It is not half as useful as Logic, for it does not prove anything, and it is always telling one of things that are not going to happen, and making one believe things that are not true. In fact, it is quite unpractical, and, as in this age to be practical is everything, I shall go back to Philosophy and study Metaphysics...” (Wilde). “«Яка безглузда річ - Кохання! - бурмотів Студент, вертаючись назад. Воно і вполовину не таке корисне, як Логіка, бо нічого не доводить, а ще завжди говорить про те, що ніколи не трапляється, і примушує вірити у таке, чого не існує. Власне, від Кохання немає жодної користі, а у наш час користь - понад усе. Повернуся-но я до своєї Філософії та вивчатиму Метафізику»'.

Таким чином, роздуми про співвідношення добра й зла, любові й невдячності червоною ниткою пройшли через цю казку О. Вайльда. 3 гіркою іронією письменник висміює нездатність представників панівного класу, які звикли бачити лише практичну, матеріальну сторону життя, до розуміння духовно-цінних властивостей людської душі, що здатні до прояву гуманності й жертовності.

В одній з кращих, найбільш зворушливих і сумних казок «Вірний друг»- письменник досягає вершини сатиричного і водночас справедливого викриття жадібної і лицемірної моралі одного з головних героїв. Історію маленького трудівника Ганса, пограбованого й знищеного багатим і жорстоким Мельником, який лицемірно називає себе «його вірним другом», 
Вайльд зводить до символічного узагальнення широкорозповсюдженої проблеми корисливості у людських стосунках: "Little Hans had a great many friends, but the most devoted friend of all was big Hugh the Miller. Indeed, so devoted was the rich Miller to little Hans, that be would never go by his garden without leaning over the wall and plucking a large nosegay, or a handful of sweet herbs, or filling his pockets with plums and cherries if it was the fruit season. "Real friends should have everything in common, - the Miller used to say, and little Hans nodded and smiled, and felt very proud of having a friend with such noble ideas" (Wilde). 'Малий Ганс мав безліч друзів, та найвірнішим з усіх був Великий Г'ю - Мірошник. Так, багатий Мірошник був настільки вірний Малому Гансові, що, було, не мине його садка, аби не перехилитися через тин і нарвати букет квітів, чи оберемок духмяних трав, чи, коли достигали плоди, напхати повні кишені слив і вишень. «У справжніх друзів усе має бути спільне»,- казав Мірошник, а Малий Ганс кивав головою та усміхався: він дуже пишався, що має друга з такими шляхетними думками'.

Дійсно, доволі важко незворушно читати сумну історію Маленького Ганса, який безтурботно живе у скромній, маланькій хатинці, порається цілісінький день серед троянд, крокусів і фіалок і посміхається сонцю, радіючи його щирому теплу: "So little Hans worked away in his garden. During the spring, the summer, and the autumn he was very happy, but when the winter came, and he had no fruit or flowers to bring to the market, he suffered a good deal from cold and hunger, and often had to go to bed without any supper but a few dried pears or some hard nuts. In the winter, also, he was extremely lonely, as the Miller never came to see him then..." (Wilde). 'Отож Малий Ганс працював собі в своєму садку. Навесні, влітку й восени йому велося добре. Але взимку, коли в нього не було більше ні квітів, ні плодів, які можна було б понести на базар, він сидів холодний і голодний і часто лягав спати, повечерявши кількома сухими грушками чи твердими горіхами. До того ж узимку він був дуже самотній, бо в ту пору Мірошник ніколи не навідувався до нього'.

3 точки зору автора, ця красива, але сумна казка ідеальна для допомоги в становленні певної системи цінностей особистості. Ї̈і мораль надто очевидна: працьовитість, чуйність, жертовність, великодушність Маленького Ганса брехливий Мельник-ледацюга знищив, возвеличивши власну мізерність та жебрацтво душі.

"What do you want, little Hans?"

"The Miller's son has fallen from a ladder, and has hurt himself, and the Miller wants you to come at once."

"All right!" said the Doctor; and he ordered his horse, and his big boots, and his lantern, and came downstairs, and rode off in the direction of the Miller's house, little Hans trudging behind him. But the storm grew worse and worse, and the rain fell in torrents, and little Hans could not see where he was going, or keep up with the horse. At last he lost his way, and wandered off on the moor, which was a very dangerous place, as it was full of deep holes, and there poor little Hans was drowned. His body was found the next day by some goatherds, floating in a great pool of water, and was brought back by them to the cottage.

- А що там у тебе скоїлося, Малий Гансе?

- Та це в Мірошника, його найменший хлопець упав 3 драбини і побився, і Мірошник просить, щоб ви швидше приїхали.

- Гаразд! - відповів лікар і звелів, щоб йому засідлали коня й приготували чоботи та ліхтар; потім сам зійшов униз, сів на коня і рушив до Мірошника, а Малий Ганс підтюпцем побіг за ним. 
А вітер усе дужчав, і дощ полив, як з відра. Малий Ганс не встигав за конем і не бачив, куди йти. Зрештою він збився з дороги й забрів на дуже небезпечне болото. Там бідолашний Ганс і втопився в глибокій ямі. Наступного дня його знайшли вівчарі й принесли до його хатини'.

О. Вайльд настільки яскраво вимальовує позитивного і негативного героя, що читачеві залишається запам'ятати вчинки одного та іншого і зробити належний висновок. Однозначно, після прочитання казки виникає питання: «А чи варто було жертвувати власними інтересами, майном і головне - життям?». Але головний герой хоч і був бідняком за своїм соціальним станом, але найбагатшим був в плані високоморальності, довіри, добра і жертовності. Він мислив іншими категоріями, які розуміються серцем, що не є кам'яним, а б'ється й живе для того, щоб вміти бачити щастя у маленьких речах, вміти співчувати і дарувати просто так. Крім того, Ганс міг щиро ділитися цими радощами, не шкодуючи і не вимагаючи потім нічого натомість.

\section{3. Висновки}

Потрібно зробити висновок, що Оскар Вайльд творив у період часу, коли існувало переконання, що в реальному житті з його матеріалістичними проявами немає нічого цінного для справжнього мистецтва, яке має приймати ідеальну та витончену форму, але його зміст не повинен перетинатися з тим, що оточує нас у повсякденні. Вайльд вважав, що не тільки життя повинне впливати на мистецтво, змінюючи його, а й мистецтво на життя, ці два поняття нерозривно пов'язані. А краса, яку можна побачити лише тоді, коли прагнеш цього, повинна впливати позитивно на людей, які могли б порівнювати себе з персонажами Вайльдівських творів і замислюватися про справжні цінності душі людської, у нашому випадку - це жертовність.

Отже, творча витонченість у побудові фраз, важливість інтонацій та парадоксальна форма вираження думки, часте використання прийому контрастного протиставлення, надмірність екзотичних, надривних, емоційних моментів стали складовими вражаючого концепту у Вайльдівських казках - почуття жертовності. Варто підкреслити, що у нашому дослідженні концепту «жертовність» ми прагнули показати саме за допомогою казок письменника дієвий елемент цього поняття. Не може існувати подібна людська цінність без реальних вчинків, які слугують найкращим доказом правдивості вияву цієї високоморальної людської якості.

Жанр літературної казки надав Вайльду чудову можливість втілити свій найважливіший життєвий принцип, згідно з яким творчість не є «імітацією життя», оскільки «описує те, чого ніколи не було», а глибинним баченням реальності у всіх її фантасмагоричних проявах. У своїх казках Оскар Вайльд звертається до вічних цінностей - любові, співчуття, жертовності заради розради інших. Стиль розповіді митця сповнений моральності, де основними проблемами виступають людські почуття та взаємостосунки. В казках О. Вайльда могутня зброя авторського слова спрямована проти лицемірства і надмірного прагматизму епох та проти жорстокості, марнославства та користолюбства, притаманних людям у всі часи. Поряд із безжальним викриттям недоліків буремного буття, казки Оскара Вайльда містять пристрасну, щиру жагу добра, співчуття, любові «агапе», жертовності і краси. 


\section{СПИСОК ЛІТЕРАТУРИ \\ (REFERENCES)}

Abelyar, P. (2007). Istoriya moyikh strazhdan. Lviv: Litopys.

Fromm, E. (1989) The Art of Loving. New York : Perennial Library.

Khrystofora S. The notion of sacrificing: Retrieved October 2, 2019, from https://www.eduugcc.org.ua/4-krok-zhertovnist-ta-podolannya-ehojimu/

Kolbe, M. (2019). Slovo o kreste. Retrieved October 20 from http://www.heroes-of-faith.com/ kolbe-biography.php

Spyrkyn, A. (1999). Fylosofyya. M. : Hardaryky.

Wilde, O. The Devoted Friend. Retrieved October 2, 2019, from https://www.weblitera.com/ sync/?id=70\&11 $=1 \& 12=2 \& 1=\mathrm{ru}$

Wilde, O. The Nightingale and the Rose. Retrieved October 2, 2019, from http://english-da.ru/ skazki/nightingale-and-rose-part1

Wilde, O. The Happy Prince. Retrieved October 2, 2019, https://www.wilde-online.info/thehappy-prince.html

Wilde, O. Shhaslyvyj prync. Retrieved October 2, 2019 from https://dobra-kazka.in.ua/kazkyza-avtoramy/uajld-oskar/shhaslivij-princ/

Wilde, O. Virnyj drugh. Retrieved October 2, 2019 from https://www.ukrlib.com.ua/world/ printit.php?tid=273 